Горан Н. ЗЕЉИЋ

Универзитет у Београду

Учитељски факултет
Оригинални научни рад

Примљен: 31.10 .2019 .

Прихваћен: 12.02 .2020$.

\title{
КОМБИНОВАЮЕ ВЕРЗАЛНИХ СКРАЋЕНИЦА И НЕСКРАЋЕНИХ РЕЧИ У СРПСКОМ ЈЕЗИКУ
}

\begin{abstract}
У раду су анализиране конструкције са верзалном скраћеницом као првим чланом и нескраћеном речју. Реч је о савременој појави која у српски језик као готов модел улази из енглеског језика. Модел конструкције типа ЕУ програми, ФИФА судија, који све више замењује уобичајени и стандардизовани образац по коме је верзална скраћеница иза именичког појма, одликује десемантизованост верзалне скраћенице и њена непроменљивост (понаша се као придеви типа соло, гала или тегет у синтагми с именицом).
\end{abstract}

Кључне речи: скраћенице, акроними, правопис, нормирање.

\section{1. Увод}

1. Скраћенице представљају економичан вид и писаног и говорног комуницирања. Њихово учешће у савременој комуникацији све је веће, ${ }^{1}$ можда и претерано (Брборић 2016: 81). У складу с тим мењао се и њихов правописни статус. Актуелна подела настала је основу постанка и начина скраћивања и подразумева следеће групе: опште (домаће), мерне и опште међународне, верзалне и вербализоване (Пешикан и др. 2010). На основу тога шта се скраћује, разликујемо скраћенице појединачних речи, израза и вишечланих (сложених) назива. Правописном нормом утврђени су начини скраћивања, који су подразумевали број и одабир слова која ће ући у скраћеницу, (не)писање тачке, променљивост. Надређени, примарни критеријум јесте препознатљивост скраћенице. О свему овоме у литератури је доста писано (Николић 1953; Стевановић 1953; Тафра 1975-1976; Николић Д. 1985; Фекете 1993; Збиљић 1997; Шубарић 2017).

\footnotetext{
"goran.zeljic@uf.bg.ac.rs

${ }^{1}$ Имамо и речнике скраћеница (Зидак 1971; Стојковић 1997; Оташевић Ђ./Оташевић Љ. 2010; 2011).
} 


\section{2. Нормирање верзалних скраћеница}

1. У односу на остале врсте скраћеница, питање нормирања верзалних скраћеница је далеко сложеније, поготово када се има у виду и њихова актуелност. Наиме, као најчешће скраћенице вишечланих назива, временски су често ограничене (попут СФРЈ, СССР, ДДР, КГБ, СИЗ, ОУР и сл.). Друга карактеристика, која је у вези са њиховом фреквентношћу, јесте и питање географске препознатљивости. Тако су типично „београдске” скраћенице СКЦ (читамо с-к-ц; значење Студентски културни центар), КСТ (читамо ка-ес-те; значење Клуб студената технике) итд. Треће питање је да ли их, као курентне скраћенице, читамо као целовите речи (оно што оне значе) или као скраћенице.

2. У првом систематски конципираном правописном приручнику, правопису А. Белића, скраћенице су представљене индиректно, у делу посвећеном интерпункцији, када су разматране већином курентне скраћенице (Белић 1923; 1934; 1952). Верзалних скраћеница (акронима) код Белића је мало (попут С. К. А. - са тачкама и белинама; у значењу Српска краљевска академија; Белић 1934: 94). Налазимо их у последњем издању и то пре свега у правописном речнику (АВНОJ - Белић 1952: 129; АПВ - Аутономна Покрајина Војводина - 131; АФЖ - Антифашистички фронт жена - 132; ИНО - Извршни народни одбор - 223; ИОНФ - Изврини одбор Народног фронта - 223; JA - Југословенска армија - 233; ЈНА - Југословенска народна армија - 233).

3. Своје место, сада не више индиректно, верзалне скраћенице су нашле у Матичиним правописима. У првом, из 1960. године, у XV поглављу, на пет страна, представљене су врсте скраћеница и правила о скраћивању речи. Верзалне скраћенице, у Правопису из 1960. назване сложеним, подељене су

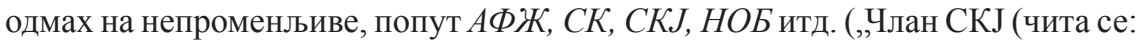
Савеза комуниста Југославије"; Стевановић/Јонке 1960: 128)) и променљиве са падежним наставком после цртице (,учествовао је у НОБ-у”; Стевановић/Јонке 1960: 129). Занимљиво је да је у Правопису из 1960. наговештено оно што ће се у савременој пракси подразумевати и што ће довести до тога да се верзалне скраћенице десемантизују, јер се за њих на истој страници каже: „у облику нових променљивих речи са својим родом, бројем, акцентом и падежним наставцима - ушле су у речник нашег језика и чешће су у употреби него сложени изрази од којих су скраћивањем постале" (нпр. и данас актуелна скраћеница Танјуг - Телеграфска агенција нове Југославије; Стевановић/Јонке 1960: 129). Такође, у делу посвећеном цртици као правописном знаку испред падежних наставака, за ове скраћенице користи се назив скраћенице етикете (нпр. Свим НО-има (народним одборима); Стевановић/Јонке 1960: 121).

4. Даље нормирање верзалних скраћеница настављено је Матичиним издањем из 1993. године. Ново у односу на претходно издање јесте прво терминологија - сада су то верзалне скраћенице или акроними. Друго, истакнута је њихова несталност, супротна већином постојаности курентних скраћеница типа $u$ др., тзв., и сл., нпр. Правила којима се нормира њихова употреба су далеко сложенија, јер се стандардизују и домаће и стране скраћенице (како 
преводне, тако и оне у изворној латиници). Такође, деклинабилности верзалних скраћеница посвећено је више простора, са јасно исказаном опцијом да се из те деклинабилности може прећи у вербализацију (нпр. Би-Би-Cu-из Би-Би-Сија-из Бибисија; Пешикан и др. 1993: 299). У овом делу посвећеном верзалним скраћеницама нема спојева са верзалном скраћеницом на првом месту, али их има у делу посвећеном спојеном и одвојеном писању речи (TB програм ${ }^{2}, T B$ водич; Пешикан и др. 1993: 89) у делу посвећеном (не)писању цртице.

5. У издању из 2010. године задржана су основна правила посвећена верзалним скраћеницама, а у делу о вербализацији налазимо и неколико примера који у ствари представљају претечу спојева типа ЦИА агент. Наиме, вербализацијом ЦИА > Ција ${ }^{3}$ омогућено је извођење придева Цијин, те добијамо спој са придевом као конгруентним атрибутом - Цијин агент, исто Насини планови, Удбин промамај, Ознина акиија, Бијин сарадник (Пешикан и др. 2010: 149) уместо конструкције с генитивом вербализоване скраћенице (агент Ције), која је такође нормативна. Други начин, забележен у пракси, јесте са придевским суфиксом и падежним наставком после цртице (нпр.: План [je] да наша земља угаси осам ЕПС-ових термоблокова (Политика, 6-7. 1. 2019, 16).).

6. У Правопису из 2010. забележене су устаљене комбинације са верзалном скраћеницом TB: TB емисија, TB програм - које су и раније нормиране (у вези са писањем цртице - Пешикан и др. 2010: 83; в. и Пешикан и др. 1993: 97 - дублетно TВ(-)програм) 4 . Међу примерима су и они латинични, типа CGS систем (центиметар-грам-секунд систем јединица), MKS систем (метар-килограм-секунд систем јединица), те оне попут TA neћ, уз коју је дат и изговор (,термоакумулациона пећ”).

7. Коначно, могућност да се равноправно користе оба обрасца дат је у Симићевом правопису (2016: 128) у вези са писањем цртице: нпр. резолуција УН/УН резолуција.

\section{3. Конструкције с верзалном скраћеницом и нескраћеном речју}

1. За скраћеницом посежемо у писању ради уштеде у простору и времену, али је можемо прочитати и као целу реч (целе речи). Међутим, код већег броја примера које смо забележили то је немогуће или би било веома апсурдно и то на више начина. Наиме, у досадашњој пракси, барем у већини случајева, верзална скраћеница је долазила после именице као управног члана, на пример Гледали смо програм РTC-а (читамо „ер-те-еса” са променом у мушком роду или „програм Радио-телевизије Србије”), он је члан

\footnotetext{
${ }^{2}$ Дублетно: ТВ(-)програм (Пешикан и др. 1993: 475).

${ }^{3}$ У пракси понекад и погрешно: Ја сам из ЦИЕ (Ладлам 1990: 252).

${ }^{4}$ У Хрватском правопису Института за хрватски језик и језикословље (Јозић и др. 2013: 80) такође су забележени спојеви са верзалном скраћеницом испред именичког појма, али опет у вези са спојеним и одвојеним писањем (без цртице, као две речи).
} 
ДС- $а$ (читамо „члан де-еса” или „члан Демократске странке”) и сл. Код неких нових спојева са верзалном скраћеницом у иницијалној позицији нема те могућности: Има рачун у НЛБ банци (Има рачун у „ен-ел-бе” банции или *Има рачун у Новој љубљанској банции банцич; пошто је иницијал Б у скр. НЛБ скраћеница за именицу банка), Суђење НВО активистима у Египту почиње 26. фебруара (Блиц, 18. 2. 2012) : Суђење *невладина организащија активистима у Египту... итд. Ако бисмо желели да прочитамо цео израз уместо скраћенице, опет бисмо морали скраћеницу пребацити иза именице (нпр. Суђење активистима невладиних организаиија).

2. Управо тај тип комбиновања верзалне скраћенице и нескраћене речи предмет је наше анализе. У пракси тај модел са верзалном скраћеницом на првом месту све је заступљенији, а у нашој анализи обухваћено је тридесетак спојева тог типа.

Табела 1: Примери верзалних скраћеница у конструкиији с нескраћеном речју

\begin{tabular}{|c|c|c|}
\hline $\begin{array}{l}\text { Верзална } \\
\text { скраћеница }\end{array}$ & Значење & Пример \\
\hline АТП & Association of Tennis Professionals & АТП титула \\
\hline БАФТА & British Academy of Film and Television Arts & БАФТА награда \\
\hline БДП & бруто домаћи производ & БДП Србије \\
\hline БИГЗ & Београдски издавачко-графички завод & БИГЗ школство \\
\hline BAP & video assistant referee & ВАР судија \\
\hline ВИП & very important person & ВИП особа \\
\hline ГМО & генетски модификован организам & ГМО храна \\
\hline ДНК & дезоксирибонуклеинска киселина & ДНК анализа \\
\hline EУ & Европска унија & ЕУ фонд \\
\hline ИТ & информационе технологије & ИТ смер \\
\hline ЛЕД & light-emitting diode & ЛЕД расвета \\
\hline LCD (ЛЦД) & liquid crystal display & ЛЦД телевизор \\
\hline MTC & Мобилна телефонија Србије & МТС корисник \\
\hline HACA & $\begin{array}{l}\text { National Aeronautics and Space } \\
\text { Administration }\end{array}$ & НАСА њушкало \\
\hline HATO & North Atlantic Treaty Organization & НАТО бомбардовање \\
\hline НБА & National Basketball Assotiation & НБА лига \\
\hline $\mathrm{HBO}$ & невладина организација & НВО сектор \\
\hline
\end{tabular}




\begin{tabular}{|l|l|l|}
\hline НЛБ & Нова љубљанска банка & НЛБ банка \\
\hline НЛО & непознати летећи објекат & НЛО систем \\
\hline НФЛ & National Football League & НФЛ играч \\
\hline ОВК & Ослободилачка војска Косова & ОВК командант \\
\hline ПИО & Пензијско и инвалидско осигурање & ПИО фонд \\
\hline ПВЦ & поливинил хлорид & ПВЦ столарија \\
\hline ПР & риblic relations & ПР агенција \\
\hline СЕХА & South East Handball Association & СЕХА лига \\
\hline СМС & Short Message Service & СМС порука \\
\hline УЕФА & Union Europeenne de Football Association & УЕФА правилник \\
\hline USВ & universal serial bus & USВ кабл \\
\hline ФИФА & $\begin{array}{l}\text { Federation Internationale de Football } \\
\text { Association }\end{array}$ & ФИФА судија \\
\hline ЦЕФТА & Central European Free Trade Agreement & ЦЕФТА споразум \\
\hline ЦИА & Central Intelligence Agency & ЦИА агент \\
\hline
\end{tabular}

\section{3. Примери:}

Пред Швајцарцем је велики улог: јубиларна 100. АТП титула у каријери (Политика, 8. 11. 2018, 19). „Краљевом говору” највише БАФТА награда ${ }^{5}$ (Вечерње новости, 14. 2. 2011, наслов). БДП Србије реално порастао за 2,3 одсто у првом кварталу (Политика, 30. 4. 2019, наслов). Хрвати тако практично држе монопол на тржишту уџбеника у Србији пошто је Жужул власник београдског „БИГЗ школства” (Блиц, 22. 5. 2018). О ВАР технологији за Телеграф је говорио лиценцирани ВАР судија Далибор Ђорђевић (Телеграф, 27. 08. 2019). Коме ће све остати ротације: блинкери за само 10 ВИП особа (Блиц, 13. 10. 2013 , наслов). Једемо ГМО храну, а да то не знамо (Блиц, 16. 8. 2015). ДНК анализа није холивудски филм (Политика, 4. 11. 2018, наслов). Користимо ЕУ фондове и у борби против пораста малигнитета (Вечерње новости, 4. 4. 2018). Овај круг преквалификација односи се само на запослене и то оне кандидате који нису на ИТ позицијама или нису завршили неки од ИТ смерова на факултетима (Политика, 9. 11. 2018, 10). Из Ниша ЛЕД ${ }^{6}$ расвета за Централну и Југоисточну Европу (Политика, 28. 7. 2017). За ЛЦД телевизоре се може чути да им је век трајања нешто краћи (Политика, 25. 2. 2009). МТС корисници власници нових „Ајфон 7” модела (Вечерње новости, 14. 10. 2016). Професионално НАСА њушкало (Данас, 2. 11. 2018, наслов). Својевремено [су] били највећи критичари НАТО бомбардовања (Политика, 8. 11. 2018, 22). Словеначки кошаркаш је тренутно први стрелац међу дебитантима НБА лиге (Политика, 8. 11. 2018, 19). НВО сектор тражи од Вучића наставак преговора у Бриселу (Данас, 31. 3. 2018). Продаје се словеначка НЛБ банка (Политика, 15. 10. 2018). Невидљив [је] за било коју врсту НЛО радарских система (Данас, 11. 9. 2018). Агим Чеку, ОВК командант, самоуверено је поручио: „Зидај зид!” (Политика, 6-7. 1. 2019, 1). Квалитет и дуговечност ПВЦ столарије зависе од количине адитива (Политика, 8. 5.

${ }^{5}$ И у конструкцији с вербализованом скраћеницом: „Ла ла ленд” плеше и за Бафта награде (Политика, 15. 1. 2017, наслов).

${ }^{6}$ И као курентна скраћеница: Јавна расвета са лед сијалицама (Политика, 28. 2. 2017, наслов). 
2007). Раднику ПИО фонда две и по године затвора (Политика, 9. 11. 2018, 9, наслов). Цвијетин Миливојевић, директор ПР агенције „Прагма”, каже да треба правити разлику између ПР менаџера и портпарола (Политика, 21. 3. 2009). Српски рукомет наредне сезоне имаће два тима у СЕХА лиги (Блиц, 7. 7. 2017, наслов). УЕФА Правилник о антидопинг контроли (Фудбалски савез Србије). Напајање се врши преко УСБ кабла (Вечерње новости, 6. 3. 2010). Бивши ФИФА судија Тановић: Португалски арбитар пријатно изненадио (Журнал, 8. 8. 2019). Председник Србије Александар Вучић рекао је јуче да очекује од ЕУ

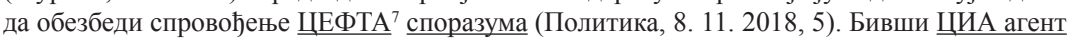
наставља да помаже њујоршкој полицији (Вечерње новости, 18. 8. 2019).

4. Конкретно, карактеристике ових конструкција биле би:

a) распоред чланова конструкције је по страном моделу - јер се често преузимају из страног језика (EU funds - EУ фондови);

б) нема дилеме у вези са (ин)деклинабилношћу верзалне скраћенице - сада се деклинира именички део: Фондови ЕУ/Фондови EУ-a : EУ фондови, ЕУ фондова, ЕУ фондовима итд.;

в) верзална скраћеница је десемантизована и понаша се као етикета - често именица која се додаје скраћеници већ постоји у скраћеници:

CMC порука (Short Message Service); НВО организација (невладина организација);

НЛБ банка (Нова љубљанска банка); ВИП особа (very important person);

ЦЕФТА споразум (Central European Free Trade Agreement)

5. Међу верзалним скраћеницама приказаним у Табели 1 разликују се оне које су уклопљене у систем ${ }^{8}$ који подразумева да скраћеницу можемо прочитати као целу реч (нпр. БДП Србије = бруто домаћи производ Србије), и оне код којих је то немогуће. Првој групи припадају, дакле, оне које имају апелативну или придевску вредност. У односу на њих, имали смо и раније несистемске спојеве попут ХТЗ опрема (хигијенско-техничка заштита = XT3). Другу групу чине већином стране скраћенице преузете из најчешће енглеског језика као што су ФБИ, УЕФА итд. Оне су адаптиране у изговору и писању и то преко спеловања (ФБИ - E $\phi-Б и-A j$, па је и тако пишемо), вербализовања (ФИФА - Фифа, Фифе, Фифи итд.) или превођења (OECD - енгл. Organisation for Economic Co-operation and Development - срп. ОЕБС - Организација за европску безбедност и сарадюу), али се у пракси не читају као целовити називи јер се често и не зна који вишечлани назив је на овај начин скраћен.

6. Иако овај модел постоји у нашој језичкој пракси одраније ${ }^{9}$ (ПП апаpam, ПТТ саобраћај, ТВ претплата и сл.), у савременом језику обухватио је и конструкције са верзалном скраћеницом које су имале уобичајени ре-

\footnotetext{
${ }^{7}$ И нестандардно: На овај потез, којим се иначе крше правила ЦЕФТЕ, косовске власти одлучиле су се упркос захтеву Европске уније (Политика, 8. 11. 2018, 5).

${ }^{8}$ Правило да се верзална скраћеница испред именице увек може прочитати као цела реч, тј. израз није дато експлицитно, већ оно произлази из примера уз које стоји и како се читају.

${ }_{9}^{9}$ Још у Политици 1930 (1. јун), у оквиру огласа нашли смо пример са верзалном скраћеницом НСУ (скраћеница од имена града Некарсулма у Немачкој, а назив компаније NSU Motorenwerke AG): NSU возачи добили су (златне плакете).
} 
дослед чланова са верзалном скраћеницом на другом месту (нпр. УН резолуција, ЕУ фондови и сл. ум. резолуција УН, фондови ЕУ), које се директно преузимају из енглеског језика (EУ фондови - EU Funds; УН резолуција - UN Resolution и сл.; ФИФА Правилник о антидопинг контроли - FIFA AntiDoping regulations).

7. Уз овај тип верзалних скраћеница појављују се и оне које нису састављене од иницијалних слова вишечланог назива, већ представљају форманте попут АЛУ од алуминијум(ски) у споју с верзалном скраћеницом ПВЦ или самостално ${ }^{10}$, на пример Да ли заиста ПВЦ и АЛУ столарија могу себе да исплате кроз мање рачуне за струју (Еспресо, 10. 8. 2018).

8. Посебно питање је и њихова променљивост. Наиме, верзалне скраћенице се могу деклинирати, и то двојако: или додавањем падежног наставка

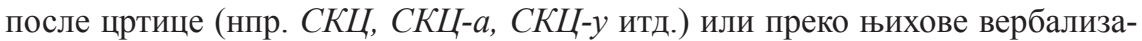
ције (УEФA - Уефа, Уефе, Уефи итд.). Дилема да ли су верзалне скраћенице деклинабилне или не свакодневно се јавља у пракси, јер се у промени оне третирају као именице мушког рода иако често означавају скраћенице појмова у ж. роду ${ }^{11}$ (нпр. Из ДС/ДС-а јављају... - Демократска странка, наравно, уколико говорник уопште зна шта је скраћено, као у случају скраћенице ЛЦД).

9. Други аспект њихове променљивости јесте у вези са рекцијом. Тако именица испред верзалне скраћенице тражи њен одређени падеж, нпр. Прочитао сам резолуцију УН-а. Важно је напоменути да је норма у случају променљивости верзалних скраћеница флексибилна, те да је у пракси (како говорној, тако и писаној) остављено говорнику да ли ће их деклинирати или не. Чести су случајеви да у новинском тексту наилазимо на исту скраћеницу, час деклинирану, час не. ${ }^{12}$ Исто је и у спојевима са именицом. ${ }^{13}$ Новим решењем, факултативна променљивост верзалне скраћенице бива избегнута и то утврђивањем обрасца у којем она увек остаје индеклинабилна: Прочитао сам УН резолуцију, чланство је било задовољно новом УН резолуциијом итд., што је у ствари образац који примењујемо у случају индеклинабилних придева типа соло (соло тачка, соло тачке) или код назива боја попут тегет, браон и сл. (тегет мајиия, тегет мајище, тегет мајиич). Колико год ово решење имало оправдања у пракси, а под оправдањем мислимо на индеклинабилност верзалне скраћенице, читаоцима бива ускраћена могућност да дату

\footnotetext{
${ }^{10}$ И у курентној варијанти: Од додатне опреме има електричне ретровизоре, „чајлд лок” систем, магленке и алу фелне (Блиц, 6. 7. 2018).

${ }^{11}$ У писаној пракси скраћеница СПЦ (Српска православна црква) увек је непроменљива.

${ }^{12}$ Нпр.: Иронично је слушати председника који је више пута покушавао да постигне политичке поене оптужујући становнике САД без држављанства да чине злочине у САД-у (Данас, 31. 07. 2019, стр. 14).

${ }^{13}$ Извршиоци кривичнх дела иду у корак са најсавременијом технологијом, па чак и сами подмећу ДНК-а трагове не би ли истрагу усмерили на криви пут, мишљење је свих учесника прошлонедељног скупа „Форензичка анализа ДНК - примена ДНК доказа - изазови у пракси” у организацији Врховног касационог суда (Политика, 4. 11. 2018).
} 
скраћеницу прочитају као целовит назив: *Прочитао сам Уједињене нащије резолуциију. ${ }^{14}$

10. Други разлог постојања спојева овог типа јесте семантички - у вези je са значењем именица у конструкцији са верзалном скраћеницом. На пример, наслов у једним новинама је гласио: Први званични СНСелектор (Данас, 31. 07. 2019, стр. 25). Проста инверзија чланова конструкције дала би *Први званични селектор CHC-а (што схватамо као да неко селектује неког; исто бомбардовање НАТО-а ум. НАТО бомбардовање), јер додавање падежних наставака повлачи за собом и промену значења (Збиљић 1997: 24). Једино додавањем предлога из добијамо исто значење - Први званични селектор из CHC- $а$ (потицање).

11. На крају, усвајању овог модела у пракси могу допринети и сродни случајеви (по аналогији).

Нпр. аналогни/дигитални телевизор : плазма/LCD (ел-иее-де) телевизор

\section{4. Закључак}

1. Скраћенице су неминовни део наше језичке свакодневице, и то све више. Пред нормативистима стоји задатак да, пратећи актуелну праксу, колико-толико њихову употребу још детаљније уреде и стандардизују. Модел са овим распоредом чланова конструкције оправдан је:

a) када се скраћеница може прочитати нескраћено (нпр. као придев) попут ПП апарат и

б) у случајевима скраћеница најчешће страног порекла које се не могу прочитати нескраћено (као целовити изрази), нпр. ЛЦД телевизор које могу бити написане у спелованој варијанти, нпр. ел-ц̧е-де телевизор.

У другим случајевима, засад, треба применити постојећу норму.

Нпр. ум. УЕФА судија треба судија Уефе (вербализацијом) ум. ВАР технологија треба технологија ВАР-а

2. Иако је решење са цртицом било као стандардно већ примењено у пракси (по Правопису из 1993. и то с дублетним решењем попут ТВ(-)прог$p a м)$, сада би оно било неприхватљиво и косило би се с тенденцијом нормативиста да се смањи број правила о употреби цртице као правописног знака.

3. На крају, инверзивне промене овог типа у српском савременом језику и то пре свега разговорном, обухватиле су и неке друге конструкције, а не само оне са верзалном скраћеницом на првом месту. Такви су, на пример, синтагматски спојеви у којима је на првом месту назив неке робне марке (тј. бренда, данашњим језиком речено), па се чак и нека властита имена тако

\footnotetext{
${ }^{14}$ Тешко је очекивати да ће читаоци спонтано ставити одговарајући облик Уједињених нацчија резолуциију са именицом резолуција у инверзији.
} 
доживљавају, попут назива манифестације „Тесла дани” уместо конструкције с присвојним придевом „Теслини дани”" Пр. Примере бележимо и у књижевности: Данас је много чешће коришћена за гала вечере - од историчара уметности Мауриција Сераћинија, до пријема поводом отварања Гучи музеја (Браун 2014: 164). Оденула је белу свилену блузу која јој је била окачена у ормару и шик ђунко шимада костим. А онда је обула шари журдан ципеле са високом штиклом (Мураками 2010: 328).

\section{ИЗВОРИ}

\section{Блиц}

13. 10. 2013: https:/www.blic.rs/vesti/hronika/kome-ce-sve-ostati-rotacije-blinkeri-za-samo-10-vip-osoba/rdftf6r Посећено 8. 9. 2019.

7. 7. 2017: https://sport.blic.rs/ostali-sportovi/rukomet/srpski-rukomet-narednesezone-imace-dva-tima-u-seha-ligi/rg2nz4z, Посећено 9. 10. 2018.

22. 5. 2018: https://www.blic.rs/biznis/posao-od-30-miliona-evra-godisnje-tudmanov-prijatelj-drzi-polovinu-srpskog-trzista/etmnp04, Посећено 7. 11. 2018.

6. 7. 2018: https://www.blic.rs/biznis/moj-novcanik/povoljne-ponude-za-idealanporodicni-automobil-karavan/q5fkhy7, Посећено 14. 11. 2018.

Браун 2014: Ден Браун, Инферно, Нови Сад: Соларис.

\section{Вечерње новости}

6. 3. 2010: http://www.novosti.rs/vesti/naslovna/tehnologije/aktuelno.236.html:267093Mali-ali-jaki-zvucnici, Посећено 14. 11. 2018.

14. 2. 2011: http://www.novosti.rs/vesti/spektakl.147.html\%3A319137-quotKraljevom-govoruquot-najvise-BAFTA-nagrada, Посећено 7. 11. 2018.

14. 10. 2016: http://www.novosti.rs/vesti/naslovna/tehnologije/aktuelno.236. html:630019-MTS-korisnici-vlasnici-novih-Ajfon-7-modela, Посећено 14. 11. 2018.

4. 4. 2018: http://www.novosti.rs/vesti/naslovna/drustvo/aktuelno.290.html:720460Koristimo-EU-fondove-i-u-borbi-protiv-porasta-maligniteta-FOTO,Посећено 14. 8. 2019.

\section{Данас}

31. 3. 2018: https://www.danas.rs/politika/nvo-sektor-trazi-od-vucica-nastavakpregovora-u-briselu/ Посећено 9. 10. 2018.

2. 11. 2018: https://www.danas.rs/zivot/profesionalno-nasa-njuskalo/, Посећено 2. 11.2018.

31. 7. 2019, 25, штампано издање.

18. 8. 2019: http://www.novosti.rs/vesti/scena.147.html:812551-Alan-Kaming--Harizmaticni-profesor-psihopata, Посећено 11. 10. 2019.

\footnotetext{
${ }^{15}$ Како и стоји у наслову новинског чланка којим се дата манифестација најављује (Политика, 29. 6. 2016). Могућа је, и нормативно прихватљива, конструкција са присвојним генитивом, нпр. Музеј Николе Тесле, када уз име којем нешто припада употребимо и неку именичку одредбу попут атрибута (исто Улица кнеза Милоша, Црква Светог Марка и сл.).
} 


\section{Eспресо}

10. 8. 2018: https://www.espreso.rs/vesti/drustvo/279099/da-li-zaista-pvc-i-alu-stolarija-mogu-sebe-da-isplate-kroz-manje-racune-za-struju, Посећено 14. 11. 2018.

\section{Журнал}

8. 8. 2019: http://www.zurnal.rs/fudbal/srpski-klubovi-u-evropi/83693/bivsi-fifasudija-tanovic-portugalski-arbitar-prijatno-iznenadio, Посећено 4. 10. 2019.

Ладлам 1990: Роберт Ладлам, Остерманов викенд, Београд: БИГЗ.

Мураками 2010: Харуки Мураками, $1 Q 984$, књ. 2, Београд: Геопоетика.

Политика

1. 6. 1930, http://www.digitalna.nb.rs/wb/NBS/novine/politika/1930/06/01\#page/0/ mode/lup, Посећено 15. 9. 2018.

8. 5. 2007: http://www.politika.rs/sr/clanak/2073/Од-чамовине-до-ПВЦ-а, Посећено 14. 11.2018.

25. 2. 2009: http://www.politika.rs/sr/clanak/Друштво/Куповина-по-дијагонали, Посећено 14. 11. 2018.

21. 3. 2009: http://www.politika.rs/sr/clanak/79987/PR-u-sendvicu, Посећено 27. 11. 2018.

29. 6. 2016: http://www.politika.rs/sr/clanak/358207/Kultura/Teslini-dani-celogjula\#!, Посећено 21. 8. 2019.

15. 1. 2017: http://www.politika.rs/sr/clanak/372130/Film-i-TV/La-la-lend-plesei-za-Bafta-nagrade, Посећено 20. 8. 2019.

28. 2. 2017: http://www.politika.rs/sr/clanak/375256/Javna-rasveta-sa-led-sijalicama, Посећено 14. 11. 2018.

28. 7. 2017: http://www.politika.rs/sr/clanak/385824/Ekonomija/Iz-Nisa-LED-rasveta-zaCentralnu-i-Jugoistocnu-Evropu, Посећено 14. 11. 2018.

15. 10. 2018: http://www.politika.rs/sr/clanak/413320/Prodaje-se-slovenacka-NLBbanka, Посећено 14. 11. 2018.

4. 11. 2018: http://www.politika.rs/sr/clanak/414973/DNK-analiza-nije-holivudski-film, Посећено 20. 8. 2019.

8. 11. 2018, штампано издање.

6-7. 1. 2019, штампано издање.

30. 4. 2019: http://www.politika.rs/sr/clanak/428527/BDP-Srbije-realno-porastaoza-2-3-odsto-u-prvom-kvartalu, Посећено 25. 8. 2019.

Фудбалски савез Србије: http://www.fss.rs/index.php?id=1268 Посећено 9. 10. 2018.

\section{ЛИТЕРАТУРА}

Белић 1923: Александар Белић, Правопис срискохрватског књижевног јези$\kappa a$, Београд: Издавачка књижарница Геце Кона.

Белић 1934: Александар Белић, Правопис српскохрватског књижевног јези$\kappa a$, Београд: Издавачко и књижарско предузеће Геца Кон А. Д.

Белић 1952: Александар Белић, Правопис српскохрватског књижевног језика, Београд: Просвета. 
Брборић 2016: Вељко Брборић, О српском правопису, Београд: Друштво за српски језик и књижевност.

Дешић 2015: Милорад Дешић, Правопис српског језика, школско издање, Београд: Klett.

Збиљић 1997: Драгољуб Збиљић, Скраћенице, Језик данас, 2, 20-24.

Зидак 1971: Јосип Зидак, Речник југословенских скраћеница, Београд: Међународна политика.

Николић 1953: Светозар Николић, О грађењу сложених скраћеница у нашем савременом књижевном језику, Наш језик, V/1-2, 9-17.

Николић Д. 1985: Душан Николић, Писање сложених скраћеница, Наш језик, XXVI/4-5, 264-268.

Оташевић Ђ./Оташевић Љ. 2010: Ђорђе Оташевић, Љиљана Оташевић, Речник скраћеница 1 (ћирилске скраћенице), Београд: Алма.

Оташевић Ђ./Оташевић Љ. 2011: Ђорђе Оташевић, Љиљана Оташевић, Речник скраћеница 2 (латиничке скраћенище), Београд: Алма.

Пешикан и др. 1993: Митар Пешикан, Јован Јерковић, Мато Пижурица, Правопис српскога језика. Нови Сад: Матица српска.

Пешикан и др. 2010: Митар Пешикан, Јован Јерковић, Мато Пижурица, Правопис српскога језика. Нови Сад: Матица српска.

Симић 2016: Радоје Симић, Српски правопис, Београд: Научно друштво за неговање и проучавање српског језика - Јасен.

Стевановић 1953: Михаило Стевановић, Род и облици промене сложених скраћеница, Наш језик, V/1-2, 18-26.

Стевановић/Јонке 1960: Михаило Стевановић, Људевит Јонке (ур.), Правопис српскохрватскога књижевног језика, Нови Сад - Загреб: Матица српска - Матица хрватска.

Стојковић 1997: Ратко Стојковић, Универзални речник скраћеница, акронима и ознака (приручник за свакодневну употребу), Београд: „Вук Караџић”.

Taфpa 1975-1976: Branka Tafra, Promenljive kratice, Jezik, 23, 3-4, 124-125.

Фекете 1993: Егон Фекете, О читању скраћеница, Наи језик, XXIX/3-4, 327-331.

Јозић и др. 2013: Željko Jozić i dr., Hrvatski pravopis, Zagreb: Institut za hrvatski jezik i jezikoslovlje.

Шубарић 2017: Sanja Šubarić, Status skraćenica - u istorijskoj i savremenoj perspektivi, Slavistična revija, 65, 263-280.

Goran N. Zeljić

COMBINING ACRONYMS AND UNABBREVIATED WORDS IN SERBIAN LANGUAGE

Summary

The paper analyzes the constructs with the acronyms as the first component and the unabbreviated word. It is a contemporary phenomenon that comes into the Serbian language as a finished model from the English language. The construction model EU programs, FIFA Judge, which is increasingly 
replacing the usual and standardized form by which the acronym is after the noun term, is characterized by the desemantation of the acronym and its constancy (acts as an adjective of the type solo, gala, or teget in the noun phrase).

Keywords: abbreviations, acronyms, orthography, standardization. 